\title{
A Study to Evaluate the Effects of Intrathecal Nalbuphine Hydrochloride with Bupivacaine and Bupivacaine Alone on Post- Operative Analgesia in Lower Abdominal Surgeries
}

\author{
Bappa Ditya Pal ${ }^{1}$, Shailesh Kumar', Smriti Anand ${ }^{3}$ \\ ${ }^{1}$ Senior Resident, Department of Anesthesiology, Index Medical College and Hospital, Indore, M.P., ${ }^{2}$ Senior Resident, Bhagwan Mahavir Hospital, \\ Pitampura, Delhi, ${ }^{3}$ Senior Resident, Jawahlal Nehru Medical College, Bhagalpur.
}

\section{Abstract}

Background: A pain-free and stress-free post-operative period helps in early mobilization and recovery, thereby reducing morbidity and mortality. Accomplishing the subarachnoid block with local anaesthetic alone has a drawback of analgesia of shorter duration in postoperative period. Addition of opioids to local anaesthetic solution used for conduct of has subarachnoid block been found safe, devoid of any nerve toxicity and in addition it increases the quality as well as the duration of the block. Nalbuphine is a semisynthetic opioid having agonist and antagonist effects on opioid receptors and devoid of other opioid like side effects. Aim: The purpose of our study was to establish the effectiveness of intrathecal nalbuphine as an adjuvant and also the efficacy of nalbuphine for post-operative analgesia and its side effects if any. Subjects and Methods: The study conducted on 60 patients of ASA grade I and II, age group between 18-60 years, scheduled for elective lower abdominal, perineal and lower limb surgeries. Patients were randomised into two equal groups of 30 each, group I (Nalbuphine group) received $3 \mathrm{cc}$ of hyperbaric bupivacaine $0.5 \%+0.8 \mathrm{cc}$ injection nalbuphine preservative free $(0.8 \mathrm{mg})$ intrathecally, Group II(controlled group) received $3 \mathrm{cc}$ of hyperbaric bupivacaine $0.5 \%+0.8 \mathrm{cc}$ of injection normal saline intrathecally. Statistical analysis was done using appropriate tests. Results: The mean time of post-operative analgesia in nalbuphine group (Group-I) was found to be highly significant $(\mathrm{P}<0.001)$ than control group (Group-II), no patient developed any side effects in our study. Conclusion: Nalbuphine hydrochloride provides better quality of blockade as well as prolongs the post-operative analgesia when used as adjuvant with bupivacaine in spinal anesthesia.

Keywords: Analgesia, Bupivacaine, Nalbuphine.

Corresponding Author: Dr. Shailesh Kumar, Senior Resident, Department of Anesthesiology, Bhagwan Mahavir Hospital, Pitampura, Delhi.

Received: January 2019

Accepted: February 2019

\section{Introduction}

One of the major problems that patient suffers in postoperative period is pain. A pain-free and stress-freepostoperative period absolutely helps in early mobilization and recovery, thereby reducing morbidityand mortality. ${ }^{[1]}$ Subarachnoid block is a routine anaesthesia procedure for abdominal, perinealand lower limb surgeries. Achieving the subarachnoid block with local anaesthetic alone has a drawback of analgesia of shorter duration in postoperative period. Addition of opioids to local anaesthetic solution used for conduct of subarachnoid block has been found safe, devoid of any nerve toxicity and in addition it increases the quality as well as the duration of the block.

Nalbuphine is a semisynthetic opioid having agonist and antagonist effects on opioid receptors. Side effects are less; as this drug does not have significant activity on delta and sigma receptor responsible for respiratory depression and other opioid like side effects. ${ }^{[2]}$

Hence the present study is designed to quantitatively examine the effects of adding nalbuphine to hyperbaric bupivacaine hydrochloride with bupivacaine alone in spinal anaesthesia, to evaluate theefficacy, to know the duration of pain relief, to know the incidence of any side effects and complications.

\section{Subjects and Methods}

After clearance from the Institutional Ethics Committee, we conducted the study on 60 patients of ASA grade I and II, age group between 18-60 years, scheduled for elective lower abdominal surgeries.Selected patients were properly informed about the study and a written informed consent was obtained.

Patients were randomised into two equal groups of 30 each, group I (Nalbuphine group) received 3cc of hyperbaric bupivacaine $0.5 \%+0.8 \mathrm{cc}$ injection nalbuphine hydrochloride preservative free $(0.8 \mathrm{mg})$ intrathecally, Group II(controlled group) received $3 \mathrm{cc}$ of hyperbaric bupivacaine $0.5 \%+0.8 \mathrm{cc}$ of injection normal saline intrathecally.

All the patients fastened for 6-8 hours .After securing IV line, each patients were reloaded with $15 \mathrm{ml} / \mathrm{kg}$ ringer's lactate solution.Patientswere put in sitting position leaning 
forwards for injection. After complete asepsis, dural puncture was performed at L4- L5 interspace or L3-L4 interspace with a 25 gauge Quincke spinal needle.

Assessment of motor and sensory blockade was done by bromage scale and pinprick method.HR, NIBP, R.R \& SpO2 were recorded before intrathecal injection and after intrathecal injection at after $5 \mathrm{~min}, 15 \mathrm{mins}, 30 \mathrm{mins}, 45 \mathrm{mins}$, 60 mins then 30 min interval till 4 hours and then every hourly till 7 hours. Intensity of pain was measured using Visual analog scale (VAS) which ranged from 0 indicating no pain till 10 indicating severe intolerable pain. Level of Sedation was assessed preoperatively, intraoperatively and postoperatively using 1-6 points Ramsay sedation score.

Statistical analysis was done using appropriate tests. Results were described as numbers (\%) and mean+/- SD. P value $<0.05$ was taken to be significant.

Duration of study: one year.

Place: R.dgardi medical college, Ujjain.

\section{Results}

\begin{tabular}{l}
\hline Table 1: Demographic variables \\
\begin{tabular}{|l|l|l|l|}
\hline VARIABLE & GROUP I & GROUP II & P-VALUE \\
\hline Age(years) & $40.13 \pm 14.09$ & $46.90 \pm 15.88$ & 0.086 \\
\hline Weight(kg) & $58.23 \pm 9.68$ & $59.27 \pm 6.98$ & 0.637 \\
\hline Gender(M:F) & $21: 9$ & $23: 7$ & 0.873 \\
\hline ASA Grade(I:II) & $23: 7$ & $17: 13$ & 0.170 \\
\hline
\end{tabular}
\end{tabular}

\section{Table 2: Vital parameters}

\begin{tabular}{|l|l|l|}
\hline Parameters & $\begin{array}{l}\text { Group I } \\
\text { (Mean } \pm \text { SD) }\end{array}$ & $\begin{array}{l}\text { Group II } \\
\text { (Mean } \pm \text { SD) }\end{array}$ \\
\hline HR & $84.12 \pm 10.56$ & $74.6 \pm 7.6$ \\
\hline SBP & $125.84 \pm 11.32$ & $110 \pm 3.0$ \\
\hline DBP & $75 \pm 7.4$ & $64.2 \pm 5.2$ \\
\hline
\end{tabular}

There was no significant difference in hemodynamic parameters like heart rate, mean, systolic and diastolic BP, and remained within normal limits [Table 2].

Table 3: Onset and duration of sensory block

\begin{tabular}{|l|l|l|l|l|}
\hline Parameter & $\begin{array}{l}\text { Bupivacaine } \\
\text { Group } \\
(\text { Mean } \pm \text { SD) }\end{array}$ & $\begin{array}{l}\text { Nalbuphine } \\
\text { Group } \\
(\text { Mean } \pm \text { SD) }\end{array}$ & $\begin{array}{l}\text { 't' } \\
\text { value }\end{array}$ & P value \\
\hline $\begin{array}{l}\text { Onset of sensory } \\
\text { block }\end{array}$ & $2.01 \pm 0.46$ & $1.89 \pm 0.34$ & $\begin{array}{l}1.099, \\
\mathrm{df}=58\end{array}$ & $\begin{array}{l}0.276, \\
\text { NS }\end{array}$ \\
\hline $\begin{array}{l}\text { Duration of } \\
\text { sensory block }\end{array}$ & $271.63 \pm$ & $\begin{array}{l}337.47 \pm \\
31.63\end{array}$ & $\begin{array}{l}-7.473, \\
\mathrm{df}=58\end{array}$ & $0.000^{*}$ \\
\hline
\end{tabular}

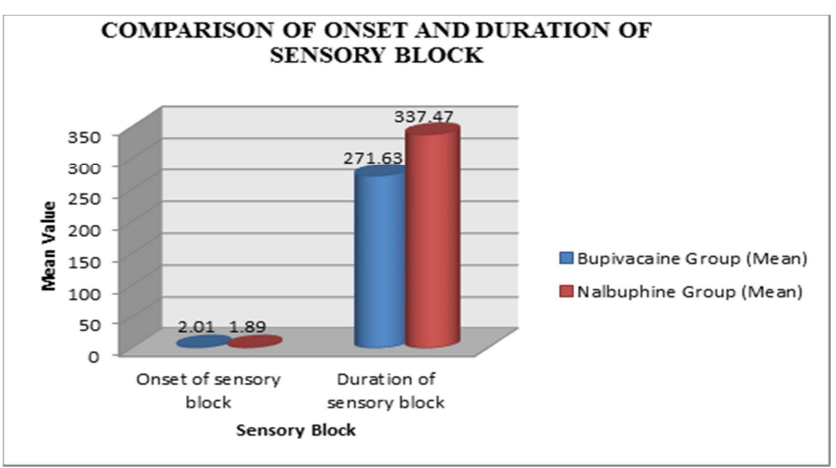

Figure 1: Comparison of Onset And Duration Of Sensory Block

A total of 60 patients took part in the study and the demographic variables like age, weight, sex ratio and ASA grade were comparable in two groups $(\mathrm{P}>0.05)$ and statistically insignificant [Table 1].

The onset of sensory block is comparable between the two groups $(\mathrm{P}>0.05)$, while the duration of sensory block is significantly longer in the Nalbuphine group in comparison to the bupivacaine group $(\mathrm{P}<0.05)$.

Table 4: Onset and duration of motor block
\begin{tabular}{|l|l|l|l|l|}
\hline Parameter & $\begin{array}{l}\text { Bupivacaine } \\
\text { Group } \\
(\text { Mean } \pm \text { SD) }\end{array}$ & $\begin{array}{l}\text { Nalbuphine } \\
\text { Group } \\
(\text { Mean } \pm \text { SD) }\end{array}$ & $\begin{array}{l}\text { 't' } \\
\text { value }\end{array}$ & $\begin{array}{l}\text { P } \\
\text { value }\end{array}$ \\
\hline Onset of motor block & $4.43 \pm 0.58$ & $4.35 \pm 0.24$ & $\begin{array}{l}0.682, \\
\text { df=58 }\end{array}$ & $\begin{array}{l}0.498, \\
\text { NS }\end{array}$ \\
\hline $\begin{array}{l}\text { Duration of motor } \\
\text { block }\end{array}$ & $\begin{array}{l}241.10 \pm \\
31.36\end{array}$ & $\begin{array}{l}369.30 \pm \\
30.66\end{array}$ & $\begin{array}{l}- \\
16.012, \\
\text { df }=58\end{array}$ & $0.000^{*}$ \\
\hline
\end{tabular}

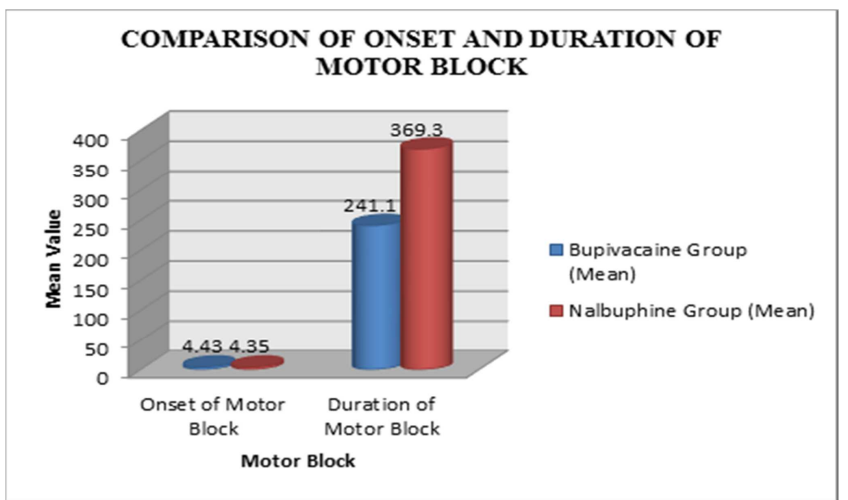

Figure 2: Comparison of Onset And Duration Of Motor Block

Onset of motor block is comparable in nalbuphine group and bupivacaine group $(\mathrm{P}>0.05)$, while duration of motor block is significantly longer in the Nalbuphine group in comparison to the bupivacaine group $(\mathrm{P}<0.05)$.

\begin{tabular}{|c|c|c|c|c|}
\hline Parameter & $\begin{array}{l}\text { Bupivacaine } \\
\text { Group } \\
(\text { Mean } \pm \text { SD) }\end{array}$ & $\begin{array}{l}\text { Nalbuphine } \\
\text { Group } \\
(\text { Mean } \pm \text { SD) }\end{array}$ & $\begin{array}{l}\text { 't' } \\
\text { value }\end{array}$ & $\begin{array}{l}P \\
\text { value }\end{array}$ \\
\hline Duration of analgesia & $4.61 \pm 0.57$ & $7.35 \pm 0.47$ & $\begin{array}{l}- \\
20.437, \\
d f=58\end{array}$ & $0.000^{*}$ \\
\hline
\end{tabular}

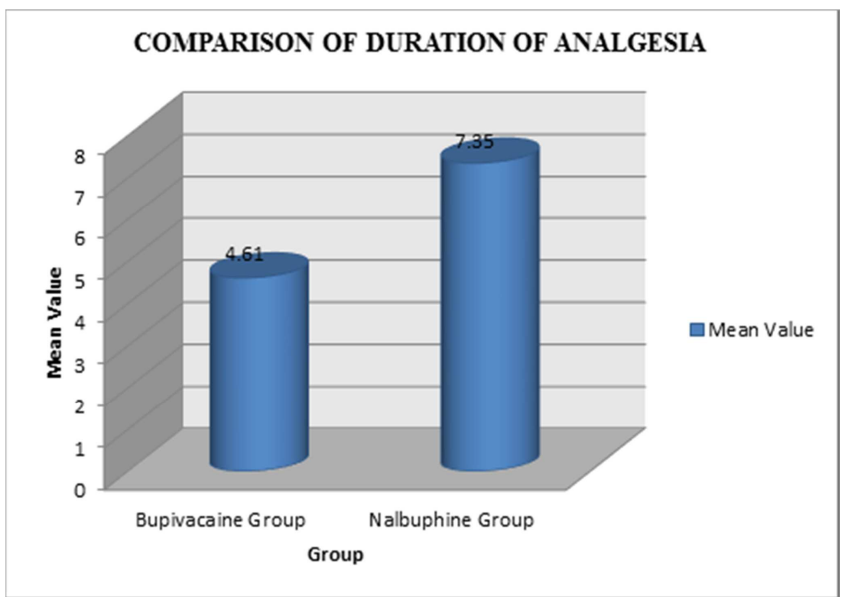

Figure 3: Comparison of Duration Of Analgesia

The duration of analgesia is significantly longer in the 
Nalbuphine group in comparison to the bupivacaine group $(\mathrm{P}<0.05)$.

\begin{tabular}{|c|c|c|c|c|}
\hline \multicolumn{5}{|c|}{ Table 6: Sedation score } \\
\hline Parameter & $\begin{array}{l}\text { Bupivacaine } \\
\text { Group } \\
(\text { Mean } \pm \text { SD) }\end{array}$ & $\begin{array}{l}\text { Nalbuphine } \\
\text { Group } \\
(\text { Mean } \pm \text { SD) }\end{array}$ & $\begin{array}{l}\text { 't' } \\
\text { value }\end{array}$ & $\begin{array}{l}P \\
\text { value }\end{array}$ \\
\hline Sedation score & $2.93 \pm 0.25$ & $2.97 \pm 0.18$ & $\begin{array}{l}- \\
0.584, \\
\mathrm{df}=58\end{array}$ & $\begin{array}{l}0.561, \\
\text { NS }\end{array}$ \\
\hline
\end{tabular}

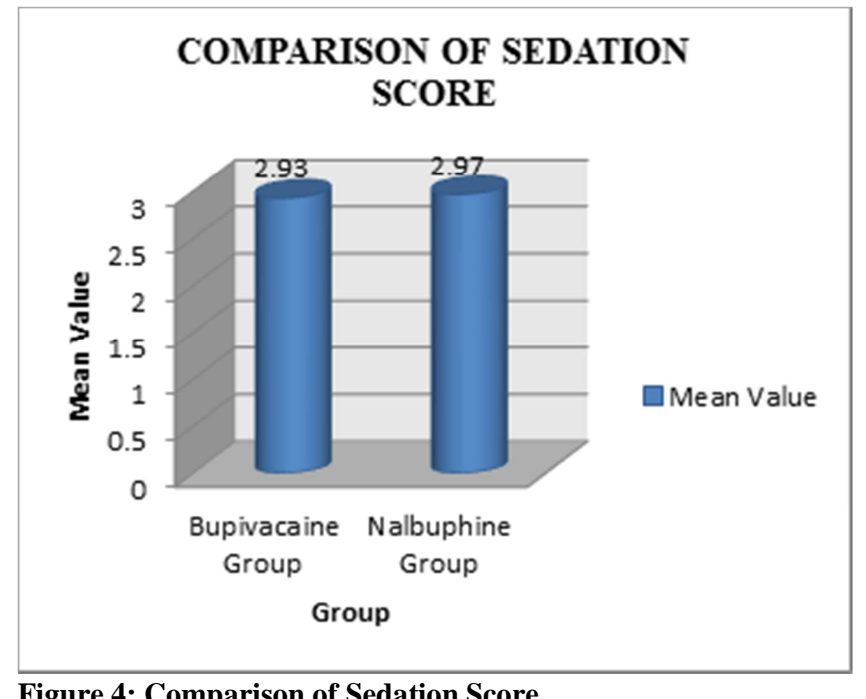

Figure 4: Comparison of Sedation Score

The sedation score is comparable between the two groups $(\mathrm{P}>0.05)$.

\section{Discussion}

This study was planned to evaluate the quality of block, duration of pain relief and incidence of adverse effects and complications if any, when $0.8 \mathrm{mg}$ of intrathecalnalbuphine is added to hyperbaric $0.5 \%$ bupivacaine in spinal anaesthesia.

We observed that the post-operative regression of sensory and motor block was significantly delayed in Group $\mathrm{N}$ than in Group B, and duration of analgesia in Group N (7.35 \pm $0.47 \mathrm{hrs})$ was significantly prolonged than in Group B(4.61 \pm $0.57 \mathrm{hrs})$. These results are in accordance with the study done by Mukherjee et al, ${ }^{[3]}$ demonstrated that the longest duration of post-operative analgesia was the group in which $0.8 \mathrm{mg}$ nalbuphine was used as an adjuvant as compared to lower doses of nalbuphine, i.e., 0.2 and $0.4 \mathrm{mg}$.

Tiwari et al 2013, ${ }^{[4]}$ concluded that the duration of sensory block and duration of analgesia was prolonged with nalbuphine without complications.

Verma et al $2013,{ }^{[5]}$ concluded that addition of nalbuphine to hyperbaric bupivacaine was effective in prolonging the duration of sensorimotor block and enhancing the postoperative analgesia following lower limb orthopedic surgery.

Ahmed et al $2016,{ }^{[6]}$ concluded that the combination of intrathecal bupivacaine with nalbuphine significantly prolonged postoperative analgesia as compared to control group and a $1.6 \mathrm{mg}$ dose showed the best results.

In our study the mean sedation score was $2.93 \pm 0.38$. Eveline Faure et $\mathrm{al}^{[7]}$ found that nalbuphine led to slightly increased sedation, Mosta aet al, ${ }^{[8]}$ observed that there were minimal side effects with sedation score comparable between the groups.

None of patient had respiratory depression (respiratory rate below $10 \mathrm{bpm}, \mathrm{SPO}_{2}<90 \%$ ). Nalbuphine exhibits ceiling effect for respiratory depression. This is proved in studies done by Romagnoli and Keats, ${ }^{[9]}$ Parveen et al. ${ }^{[10]}$ Since respiratory depression is predominantly receptor-mediated and nalbuphine is a receptor antagonist, respiratory depression effect is expected to be attenuated by nalbuphine. Thus from our study dose of nalbuphine $0.8 \mathrm{mg}$ appears adequate as an adjuvant to bupivacaine in subarachnoid block and can safely be used as adjuvant to enhance duration post-operative analgesia without increasing the side effects or complication.

The shortcoming or discrepancies found in our study can be attributed to the fact that it comprised of small sample size. The results can be better established if large sample size studies are under taken.

\section{Conclusion}

On the basis of this study addition of nalbuphine hydrochloride in dosage of $0.8 \mathrm{mg}$ to intrathecal bupivacaine $0.5 \%$ prolongs the duration of sensory block ,provides excellent and longer duration of post operative analgesia, desirable sedation, stable hemodynamic without any significant side effects.

Thus we conclude that intrathecalnalbuphine at dosage of 0.8 $\mathrm{mg}$ can be used as an effective adjuvant along with intrathecal hyperbaric bupivacaine $0.5 \%$ to have a good post operative analgesia.

\section{References}

1. Shakooh S, Bhosle P. Intrathecalnalbuphine: An effective adjuvant for post operative analgesia. InnovativeJournal of Medical and Health Science 2014;4(2):79-82.

2. Gunion MW, Marchionne AM, Anderson CT. Use of the mixed agonist-antagonist nalbuphine in opioid based analgesia. Acute Pain 2004;6:29-39.

3. Mukherjee A, Pal A, Agrawal J, Mehrotra A, Dawar N. Intrathecalnalbuphine as an adjuvant to subarachnoid block: What is the most effective dose? Anesth Essays Res. 2011 Jul-Dec;5(2):1715 .

4. Tiwari AK, Tomar GS, Agrawal J. Intrathecal bupivacaine in comparison with a combination of nalbuphine and bupivacaine for subarachnoid block: a randomized prospective double-blind clinical study. Am J Ther. 2013 Nov-Dec;20(6):592-5. doi: 10.1097/MJT.0b013e31822048db

5. Verma D, Naithani U, Jain DC, Singh A. Postoperative analgesic efficacy of intrathecal tramadol versus nalbuphine added to bupivacaine in spinal anaesthesia for lower limb orthopaedic surgery. Journal of Evolution of Medical and Dental Sciences 2013;2(33):6196-206

6. Ahmed F, Narula H, Khandelwal M, Dutta D. A comparative study of three different doses of nalbuphine as an adjuvant to intrathecal bupivacaine for postoperative analgesia in abdominal hysterectomy. Indian J Pain 2016;30:23-8.

7. Eveline Faure, MD, Bernard Wittels, MD, PhD, JeromeKlafta, MD, Alicia Toledano, ScD, Michelle Freind, DO, AtefMoawad, MD. Intrathecal fentanyl with nalbuphinefor labour analgesia Br J Anaesth 
1982; 54:479-86.

8. Moustafa MA, Saleh RS. Nalbuphine added to intrathecal morphine in total knee arthroplasty; effect on postoperative analgesic requirements and morphine related side effects. Alexandria Journal of Medicine 2012:48:175-8

9. Romagnoli A, Keats AS. Ceiling effect for respiratory depression by nalbuphine. ClinPharmacolTher 1980;27:478-85.

10. Parveen S, Prasad PK, Lakshmi BS. Evaluation of the effect of intrathecalnalbuphine as an adjuvant to spinal bupivacaine for postoperative analgesia in patients undergoing abdominal hysterectomy: a randomized, double-blinded control trial. Int J Sci Stud 2015;3(8):1416.

Copyright: () the author(s), publisher. Academia Anesthesiologica International is an Official Publication of "Society for Health Care \& Research Development". It is an open-access article distributed under the terms of the Creative Commons Attribution Non-Commercial License, which permits unrestricted non-commercial use, distribution, and reproduction in any medium, provided the original work is properly cited.

How to cite this article: Pal BD, Kumar S, Anand S. A Study to Evaluate the Effects of Intrathecal Nalbuphine Hydrochloride with Bupivacaine and Bupivacaine Alone on Post-Operative Analgesia in Lower Abdominal Surgeries. Acad. Anesthesiol. Int. 2019;4(1):57-60.

DOI: dx.doi.org/10.21276/aan.2019.4.1.13

Source of Support: Nil, Conflict of Interest: None declared. 